\title{
Joseph Cardinal Ratzinger [Pope Benedict XVI] - Truth and Tolerance: Christian Belief and World Religions
}

(San Francisco: Ignatius Press, 2004). 284 pp. ISBN 1-58617-035-x. US\$ 12,21; republ. as Amazon Kindle edition (e-book) in 2009 [original German title: Glaube-Wahrheit-Toleranz. Das Christentum und die Weltreligionen (Freiburg im Breisgau: Herder Verlag, 2003)].

\section{Christoph Marcinkowski International Institute of Advanced Islamic Studies}

Pope Benedict XVI has dealt in quite a number of his works with the issues of secularisation and contemporary religious and cultural identity. Many of these works are now also readily accessible in English. ${ }^{1}$ It would be a rewarding task to collate his approach with those of thinking representatives of contemporary Muslim thought. ${ }^{2}$ In Truth and Tolerance, Benedict - still Prefect of the Congregation for the Doctrine of the Faith at the time when its original German edition went to the press - presents, aside from some new contributions, milestone-articles that he has published over the last 15 years in the field of 'theology of religions' in various journals. What Benedict has to say about interfaith relations today might also be of interest to the audience of this journal, since he is in the Muslim world - usually exclusively (and perhaps selectively) - associated with his 2006 'Regensburg lecture' which was perceived by some as misrepresenting the religion of Islam. ${ }^{3}$

In the first part of this collection (13-109), Ratzinger addresses the topic of the Christian faith in the encounter with other cultures and religions, where he makes the important point that something like a 'theology of religions' was not yet a central concern at the time of Vatican II, during the 1960s. The rather 'incidental' Declaration Nostra aetate, however, has subsequently proven to be particularly forward-looking. In order to document the discussion back in those days, the current pope has included in this collection his article "The Unity and Diversity of Religions: The Place of Christianity in the History of Religions" (15-44), which was published back in 1964 in the Festschrift for Karl Rahner (1904-1984), one of the most influential Catholic theologians of the twentieth century. The lecture "Faith, Religion, and Culture" (55-79), which was presented by Ratzinger in 1992 at the "Salzburg University Weeks", contains reflections on the right and the ability of the Christian faith to inform the people of other cultures. His "Variations" on this subject (80-109), exclusively written by Ratzinger for this volume, elaborate further on this topic.

The second part of the book ("Religion and the Question of Truth", 113-258), however, is perhaps the most interesting one. Here the author confronts the phenomenon of diversity of religions with the philosophical question of truth. This part contains considerations that are typical for Ratzinger's style of clarity 
and intellectual sharpness. In "The New Questions that Arose in the Nineties: The Position of Faith and Theology Today" (115-37), a contribution that was first published in 1996, Ratzinger tries to show why present-day relativism has become the central problem for faith. According to him, a certain right to relativism in the political and social realms would certainly be acceptable. Relativism appears here as the philosophical foundation of democracy which is based on the rule that no one should claim exclusively to know the right way. However, here we also face the serious problem that relativism is understood by many as a comprehensive theory, which should be applied to the fields of religion and ethics as well. In this way, the term 'dialogue' - which certainly does play a significant role in the Christian tradition - mutates to the epitome of the relativistic credo. How can theology react to this situation? The Pope concedes the utmost importance to the quest for the limits and possibilities of reason - that is to say, the quest for the possible philosophical premises of faith, arguing in favour of a new 'dialogical' approach between faith and philosophy as both are in need of each other. The fact that today people still believe - despite all relativistic challenges of faith - can be ascribed to the fact that faith is in the end deeply rooted in the essential nature of man.

Quite remarkable are Ratzinger's reflections on "Faith, Truth, and Culture" (183-209) which take reference to the Encyclical Fides et ratio (Faith and Reason, 1998). Philosophy deals with the question of whether one is able to recognise the fundamental truth about oneself or whether one lives in some sort of epistemological twilight which needs to be 'enlightened', thus forcing one to focus on the question of what is 'useful' only. Faith, however, claims to tell us the truth about God, the world, and man. The missionary tendency of faith is based on this claim. Only when this claim contains truth it is of concern to all mankind. The question of truth is therefore also the core issue of theology. Insofar, faith is also necessarily related to philosophy. The question of truth which today is largely dismissed as 'unscientific' should thus regain its significance as a 'rational task'. Symptomatic for the current dismissal of truth - in particular in the West - is a remark by Umberto Eco, according to whom "the only truth lies in learning to free ourselves from insane passion for the truth" (The Name of the Rose, Seventh Day, Night).

The dispute over the truth is the heart of the debate of faith with a specific variant of modern culture, which itself aims at impersonating modern culture par excellence. This judgment must - according to the Pope - be considered as an attempt not to accept any other instance than a 'majority decision'. A random majority becomes the absolute. We are thus exposed to the reign of positivism and the maximisation of randomness - in other words, of the manipulable. Ratzinger, in turn, represents in his book a dynamic concept of culture: cultures are not 'fixed', they don't come in a particular shape or figure; theirs is rather the ability to progress or to transform themselves - even at the risk of decline. Cultures are laid out toward encounter and 
mutual fertilisation. They are marked by some sort of inner readiness for God's Revelation. Revelation therefore responds to an internal expectation within the cultures themselves. With regard to the importance of religions in terms of salvation, Ratzinger finds that they do not help to save the people as closed systems, but rather by causing people to seek the 'face of God'. Today, the question of truth is all too often separated from the 'theology of religions'. Truth is replaced by good intention. On behalf of good intentions, however, much evil has already happened in history. There are indeed many sickening forms of pseudo-religion today-Christianity and Islam are here no exception. The rejection of the truth, however, is incapable of leading people toward salvation, because salvation in the Hereafter depends on the quality of life in this world. The dethronement of theology and metaphysics makes thinking therefore not only appear 'freer' but also narrower. One could even speak of 'stultification by unbelief'.

In the previously unpublished article "Faith - Truth - Tolerance" (210-31), Ratzinger addresses the core issue of whether the belief in the truth of Revelation and the idea of tolerance (which belongs to the foundations of modernity) are in irreconcilable contrast to each other; in other words, "Are faith and modernity compatible?" This essay is thematically closely interconnected with the following quite thrilling chapter "Freedom and Truth" (231-58), the last piece of this collection. Here Ratzinger shows that freedom continues to be considered as the highest good in the consciousness of contemporary mankind. The concept of truth, however, is met with suspicion. Those who claim to be in the service of truth are considered dreamers or fanatics. The non-reflective 'feeling' of 'the mass' understands by 'freedom' that one's own will constitutes the only norm for proper action and that this will is able to want everything and that all what is wanted can be carried out. A proper definition of freedom must be made within the context of reason. Anything else would amount to the tyranny of stupidity. The common reason of everyone will provide for the mutual compatibility of freedoms. Ratzinger reminds us of the claim of Marxism to know the 'scientifically secured way' towards liberation. This supposed 'liberation movement', the largest slave system of modern history - next to the Third Reich - collapsed economically and politically, but has still not been overcome mentally. On the other hand, the moral superiority of the liberal system does not result in any kind of enthusiasm, because a large number of people have no share in the fruits of this freedom. Within this context, Ratzinger does also recognise the search for a 'world ethos' in the sense of Hans Küng. He doubts, however, that the rational evidence of this ethos can replace religious authority. Therefore, reason must remain open for the major religious traditions; it must say 'goodbye' to the dream of self-sufficiency. It needs to maintain the linkage with the major religious traditions of humanity. 
The consciousness that democracy as we know it today still does not represent the right form of freedom is ubiquitous now. Some might even argue, that it is doubtful, whether in democracy the welfare of the public comes enough into play. Moreover, in this form of government we often encounter also some sort of new oligarchy of those, who want to determine what an 'enlightened' person has to think. Jean-Paul Sartre, the profound freedom-philosopher of the twentieth century, could understand the freedom of man in the end only as "condemnation of human liberty'. The exciting part in Sartre's approach is that he radically performs the separation of freedom from truth; ultimately then to him there is no truth. Freedom has no direction and no measure. With this Sartre won almost tragic 'knowledge': the total absence of any metaphysical and moral binding, i.e. absolutely anarchic freedom as 'essential determination' of man, 'revealed' to those who try to live it not as the highest form of existence but as absolute emptiness. Therefore, anarchic freedom that is detached from the truth does not redeem man but can in fact only understand him as degenerated creature - as pointless existence.

In sum then, it becomes clear from this book that 'civilisational renewal' is currently not only taking place within the confines of the Muslim world, but also in Europe which is increasingly searching for its own roots. With this book Ratzinger has produced a remarkable work on those burning issues. To listen to what he has to say might therefore also open up new and perhaps more meaningful avenues for a truly intercivilisational dialogue - especially to those who come from a different tradition. In that sense, Truth and Tolerance is an important contribution to the current 'Islam and the West' debate.

\section{Notes}

1. See Joseph Cardinal Ratzinger [Pope Benedict XVI], Europe, Today and Tomorrow. Addressing the Fundamental Issues (San Francisco: Ignatius Press, 2007); idem, Christianity and the Crisis of Cultures (San Francisco: Ignatius Press, 2006); idem, Values in a Time of Upheaval (New York: Crossroads, and San Francisco: Ignatius Press, 2006); and idem and Jürgen Habermas, The Dialectics of Secularization (San Francisco: Ignatius Press, 2006).

2. For two important works in this field see Syed Muhammad Naquib al-Attas, Islam and Secularism (Kuala Lumpur: International Institute of Islamic Thought and Civilization (ISTAC), 1993) and idem, Prolegomena to the Metaphysics of Islam (Kuala Lumpur: International Institute of Islamic Thought and Civilization (ISTAC), 2001). At the time of writing, this reviewer had been working an anthology in German of some of Al-Attas' key works on those issues: see Christoph Marcinkowski (tr., ed., intro.), Islam in Südostasien: Der malaysische Denker Syed Muhammad Naquib Al-Attas zum Verhältnis von Religion und Philosophie (Buchreihe der Georges-Anawati-Stiftung, ed. Christian W. Troll and Rotraud Wielandt) (Freiburg im Breisgau: Herder Verlag, forthcoming in 2010).

3. In an earlier issue of this journal, this reviewer has already dealt with 'Regensburg' and some aspects of Pope Benedict's thought on Catholic relations with other faiths, in particular with Islam: see Christoph Marcinkowski, "Religion, Reason, 'Regenburg': Perspectives for Catholic-Muslim Dialogue Today", Islam and Civilisational Renewal (Special Issue: Islam and Pluralism) 1, no. 1 (October 2009), 159-67. See also idem, "The Basis of the Pope's Reasoning", Straits Times [Singapore] (18 September 2006), 18. 